Portland State University

PDXScholar

1973

\title{
Community Vocational Success of Institutionalized Mental Retardates as a Function of Coping Style
}

Jane C. Schilling

Portland State University

Follow this and additional works at: https://pdxscholar.library.pdx.edu/open_access_etds

Part of the Disability Studies Commons, and the Social Work Commons Let us know how access to this document benefits you.

Recommended Citation

Schilling, Jane C., "Community Vocational Success of Institutionalized Mental Retardates as a Function of Coping Style" (1973). Dissertations and Theses. Paper 1735.

https://doi.org/10.15760/etd.1734

This Thesis is brought to you for free and open access. It has been accepted for inclusion in Dissertations and Theses by an authorized administrator of PDXScholar. Please contact us if we can make this document more accessible: pdxscholar@pdx.edu. 
COMMUNITY WOCATIONAI SUCCESS OF INSTITUTIONALIZED MENTAL RETARDATES AS A FUNCTION OF

COPING STYLE

by

Jane C. Schilling

j

.......... A report submitted in partial fulfillment of the requirements for the degree of

$\therefore-2$.

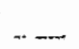

WASTER OF

SOCIAI. WORK

Portland State University 
TABLE OF OONTENTS

I. Introduction $\ldots \ldots \ldots \ldots \ldots \ldots \ldots \ldots \ldots \ldots \ldots \ldots \ldots \ldots \ldots \ldots \ldots \ldots \ldots$

II. Rationale .................................. 3

III. Definition of Coping Style ...................... II

IV. Reviow of Literature $\ldots \ldots \ldots \ldots \ldots \ldots \ldots \ldots \ldots \ldots \ldots \ldots \ldots \ldots \ldots \ldots$

V. Method $\ldots \ldots \ldots \ldots \ldots \ldots \ldots \ldots \ldots \ldots \ldots \ldots \ldots \ldots \ldots \ldots \ldots \ldots \ldots \ldots \ldots$

VI. Results $\ldots \ldots \ldots \ldots \ldots \ldots \ldots \ldots \ldots \ldots \ldots \ldots \ldots \ldots \ldots \ldots \ldots \ldots \ldots \ldots \ldots \ldots 16$

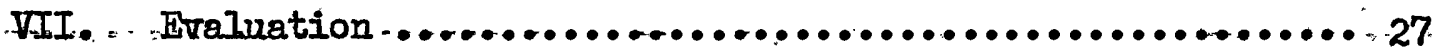

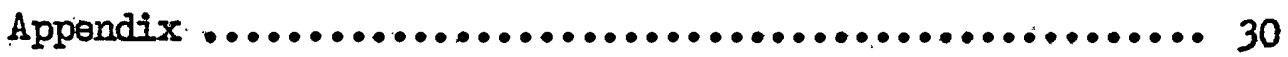

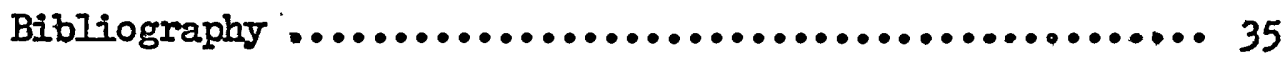

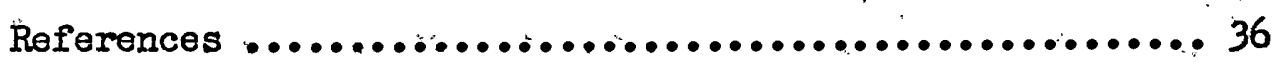


COMMONITY VOCATTONAL SUCGESS OF INSTITUTIONALIZED

MENTAL RETARDATES AS A FUNCTION OF

COPING STYLE 
CHAPTER I

INTRODUCTION

In May, 1968, Fairview Hospital and Training Center (for the Mentally Retarded) located in Salem, Oregon, initiated its first Manpower Development and Training Program (MDT) coupled with an On-The-Job Training Program (OJT). The OJT portion of the training phase was eventually renamed and is now known as the Jobs Optional Program (JOP). Since the start of the program, a total of 273 residents have participated in the institutional phase and 131 in the JOP phese:

Presently there are approximately 1,500 residents at Fairview Hospital and Training Center and a total of 20 cottages serving as regidential

- facilities. Medical services for the residents are provided by a complete

= haspital and dental department. The Feirview School provides classes ranging from pre-schoolinthrough adult-education. "Varied-recreational-programs are made available to all residents. There is a physical rehabili-. tation center for physically handicapped residents. The Vocational

- Tducation Department prov̈ides-träining for non-physically handicapped as weIl as physically hảalcapped résidénts. Each individual resident is placed on programs-designed to meet-his special needs from Iearning to

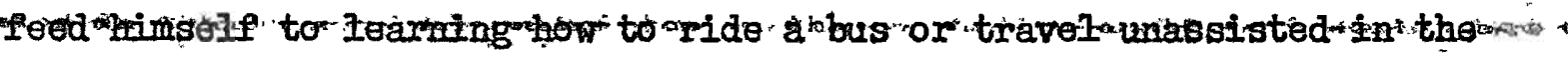
commanity.

During the five years that the program has been in existance, it has become-Increasingly apparent that some type of pre-selective, reliable testing should be used in order to better select and serve those trainees enrolled in the program. 
The four training areas of the program ( 1) Maids/Housekeeping, 2) Kitchen, 3) Nursing Home Orderly, and 4) Gustodial) offer 50 training slots per year. Reliable methods of pre-selecting trainees before admission into the program will not only help to insure the success of the program; but, more importantly; help to insure the success of the individual who will be leaving the institution to return to society and competitive empioyment. 
The purpose of this study was to develop a scale that would predict a trainee's (or potential trainee's) success or failure in the JoP phase of the program: It was felt that an individual's method of coping with everydey petterns of Iiving woujd inflimence his success ar fatiur in employment, for exampio, it was felt that if a trainee was

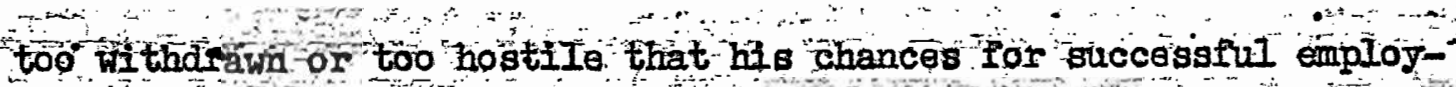
meth fouta decrease

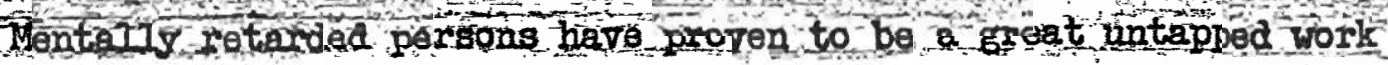
force. They are usually good; reltable; steady employees and have benafittad greatly from participation in vocational training. "As an example, from 1958 to 1967 , the number of rehabilitated nentaliy retarded rose from 1,578 to 17,724 , whila thoir proportion among all $\mathrm{r} \theta-$ habilitated persons rose from 2 of to $10 \%$ (7)

The MDr portion of the program at Fairview Hospital and Training Center provides a trainee with up. to 35 weoks of tocational instruction within the institutional setting and a 15 weok period of Jobs Optional W salar for that particular position, providing the salary is not Iess than the Federaj Manmo Wage of 1.60 per hour For tho 15 weok JOP training, the employer is reimbursed orie-half of the wages paid to the trainee.

Since the beginning of the program in 1968, it has been apparent that some way of objectively measuring the ability of the trainee enterIng the progrem was necessary: Trainees for MDT were being selected on 
the judgment of staff members and scores obtained on the Weschler Adult Inteliigence Scale (WAIS) and the Wide Range Achievement Test (WRAT). However, intelligence and achievement tests soon proved to be of littio value in measuring aptitude for rocational success. "Tho General Aptitude Test Battery (GATB) also proved to be very limited, as many of the trainees being considered for the program were unable to read.

In 1963. the Nanpower Administration began research on a battery of tests which would measure the same aptitudes as the GATB, but which could also be used for the culturally and educationally disedvantaged populations. The Non-reading Aptitude Test Battery (NATB) is the result of their experimental efforts. (3). The NATB proved to be ideal for use with the mentally retarded as it required little or no reading ability.

Studies performed at Fairview Hospital and Training Center indicate that the NATB can be used with a good amount of reliebility in predicting vocational success for a trainee in the commuity upon completion of his JOP training. (2) However, many of the trainees whose NATB scores predicted vocational success were not successful in JOP; thereby indicating a need-for continued research.

The NATB consists of 10 separate testing batteries (See Appendix A) plus five tests found in the GATB. - The tests used in the NATB are briefly, explained below.

1. Picture-Word Matching

The examinee must determine which of flve pictures associates best with a stimulus work read by the examiner. Measures general intelligence and verbaI aptitude. 
2. Oral Vocabulary

The examinee must decide whether the two words read by the examiner have the same, opposite, or different (neither) meaning. Measures general intelligence, verbal aptitude, and numerical aptitude.

\section{Coin Matehing}

The examinee must indicate whether the two groups of coins presented have the same value: Measures numerical aptitude.

\section{0" "Matrices}

This test contains 29 matrix type items of increasing difficulty. Measures general intelligence and numerical aptitude.

\section{Tool Matching}

This test contains a stimalus drawing and four drawings of simple shop tools. The examinee indicates which of the far drawings is exactly the same as the stimzlus arawing. Measures form perception.

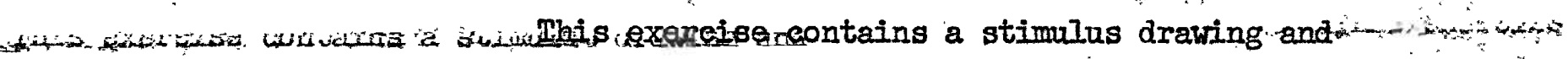
four drawings of three-dimensional objects. The. stimulus drawing is presented as a flat objeat and must be mentally bent, rolled, or both. Iines on the stimulus drawing indicate where the fold or bend is to be made. The examinee indicates which one of the four three-dimensional objects can be made from 
the stimulus drawing. Measures general intelifgence and spatial aptitude.

7. Form Matching

The test is composed of two groups of variously shaped line drawings. The examinee indicates which figure in the second group is exactly the same in size and shape as the figure in the first group. Measures form perception.

8. Coin Series

This test consists of three parts, each more difficult then the one preceeding it. The examinee is required to mentally manipulate the coins accordIng, to the assigned directions. Measures numorical appitude.

9. Name Comparison

The test is-composed of two columns of names. The examinee inspects each pair of nomes and determines whether they are exactIy the same or different.

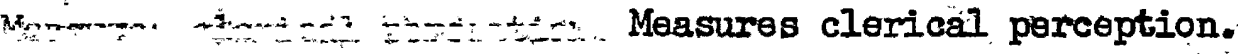

A test for speed conteining the letter "i". The examinee must-indieate which "i."s are printed upgide down. Measures clericel perception.

11. Mark Making (GATB, Part 8)

The test is composed of a series of squares. The examinee is to make three pencil marks in each 
square following a prescribed pattern (two vertical and one horizontal below them). Measures motor coordination.

\section{Place (GATB, Part 9)}

The equipment used in the place test, as well as the following test, consists of a rectangalar pegboard divided into two sections. The upper section contains cylindrical pegs. The examinee removes the pegs from the upper holes and inserts the pega in the corresponding holes in the lower section. The examinee moves two pegs at once, one in each hand. The test is administered three times and the examinee tries to move and place as many pegs as possible within a specified period of time. Measures manual dexterity.

13. Turn (GATB, Part 10)

See above for a description of the equipment used for this test. For this test, the examinee starts with all the pegs in the lower section of the board. Using hits perferred hand, the examinee removes a peg from a hole, turns it over, and replaces it in the same holle with the opposite end up." The test is administered three times and the examines attempts to turn as many pegs as possible. Measures manual dexterity. 
14. Assemble (GATB, Part 11)

The equipment used for this test and the following test consists of a small rectangular finger dexterity board, a supply of small rivets, and washers. The examinee removes a rivet from the upper part of the board with his preferred hand while at the same time removing a washer from a vertical rod with his other hand. He places the washer on the rivet and inserts the assembled piece into corresponding hole on the bottor part of the board, using only hts preferred hand. There is only a shoit period of time allowed (90 seconds) and the examinee mast work as quickly as possible to. assemble as many pieces as he can. Measures finger dexterity.

15. Disassemble (GATB, Part 12)

The equipment used for this test has been described in the test preceeding it. The examinee remores the assembled rivet from a hole in the lower part of the board with his preferred-hand. At the

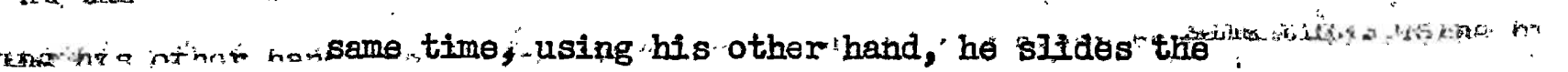
washer to the bottom of the board, He'places the washer on vertical rod with one hand and the rivet in the corresponding hole on the upper part of the board with his preferred hand. He works as quickly as he can in order to disassemble as many pleces as 
possible in 60 seconds. Measures finger dexterity.

Previous studies (I) indicate that age and academic achievement are not statistically related to an individual's Job Optional Training Performance. Three of the NATB tests have proven to be fairly reliable predictions for a trainee's success, both during and following the JOP period. These three tests are: 1) Letter Cancellation

2) Form Matching

3) Disassemble

It was noticed that of the trainees who had NATB scores predicting successful JOP pertods, many of these trainees were not completing the JOP period and/or were not being hired as full-time, regular employees following JOP training. It was felt that since these individuals shovid have been successful (besed on their NATB scores) some other variable was interfering with their chance for success.

Walter S. Neff (5) has developed a theory describing and explaining what he calls, the "work personality". His theory maintains that in order to be successful in any job setting, the individual must be able to meet the necessary conditions (mobility, manual dexterity, and ability to perform the tesk). as well as the sufficient conditions. For example, they cannot be fearful of authority; camot decide what hours or pace they will work. Upon examining the trainee in the MPr program, it-was found that they did meet the necessary conditions of their job. However, since many were failing, it was felt that they might not be meeting the sufficient conditions of their job.

It was decided to apply a Coping Scale as developed by Doctor Neff (5) to the MDT trainees who had recieved NATB scores predicting success, 
but who failed their JOP training and determine whether or not variances in coping styles might account for these differences. 


\section{DEFINITION OF COPING STYLE}

Work placemonts, by the very nature of the setting in which they take place, are social situations. Social situations are characterized, by a highly developed set of norms, customs, and demands. Neff (5) states that we should not be concerned with those individuals who are able to satisfactorily meet both the necessary and sufficient conditions of their work, "but in those who encounter major difflculties. Given that the ability to work is a function of long-term developmental process, it is important to know something about the various ways in which the process can go wrong...".

In his work, Neff has described five different typess of "work psychopathology". (5) - These-various types of psychopathology are described below.

Type 1. People who appear to have major lack of work motivation. They have a negative conception of their role as an employee.: :

The individual seems to have general indifference to the productive roleg-work serves no" wital needs of the personality Work is re sistę or evaded.

Type 2. Individuals whose predominating response, to the demand to be productive, is to manifest fear and anxiety.

The individual has learned to believe that he cannot meet the standards of being a productive 
person; that he is inept; that he is incapable; or that he is impotent.

Type 3. People who are predominantly characterized by open hostility and aggression.

To this individual any kind of supervisory criticism is seen as an attack and is actively resisted. The slightest disagreement with peers may result in open quarrels.

Type 4.- People who are characterized by marked dependency. These individuals are often able to produce effectively only under very close and continuous supervision.

Type 5. People who display a marked degree of social naivete. For these individuals, there is no understandIng of work; no conception of oneself as a worker; no knowledge of the demands and reelities of work enviroments. The problems manifested are those of simple ignorance rather than those of rejection or registance. The concept of work psychopathology, maintains that any individual. whose coping style demonstrates a marked predominance in one or more of the above catagories (types) will not be able to successfully cope with the demands of his duties as an employee. 


\section{REVIEW OF IITERATURE}

Walter S. Neff and Myron Koltov in 1967 (6) completed a study using the Coping Scale with 86 rehabilitated mental patients. Their findings indicate that "it would appear that the ability of the exmental patient to sustain a comprehensive program of rehabilitation in related to judgments concerning his characteristic coping behaviar." ...there is a tendency for patients who do not oustain such a program to exhibit greater amounts of traits which, by definition, seem maladaptive." (6, Page 369)

Studies performed by Carbuhn and Wello (1) using 125 mentally $r e=$ tarded subjects-attempted-to-identify characteristics of the work perm sonality. The results obtained were based on two criteria; the first was a 5 point 8 factor rating form completed by the work supervisor. (Appendix B) and the second was the actual amount of time spent on the" job. The obtained results indicated that "the majority of the trainees. classified into the 'below average'-gno up appear to manifest the work failure behavior characteristic of Neff', Type 4 (dependency) and especially Type 5 (social naivete)". 


\section{CHAPTER V}

\section{METHOD}

For the purpose of this study only those MDT trainees who achieved scores on the NATB predicting that they would be successful during their JOP training were sampled. The NATB tests relevant to use in this study were Letter Cancellation (Test No. 6), Form Matching (Test No. 7), and Disassemble (Test No. 15). Thesè tests are designed to measure perceptual speed (Istter Cancellation), non-verbal intelifigence (Form Matching), and manual dexterity (Disassemble).

The individuals who successfully scored on the NATB were then divided into two groups. One group was composed of those trainees whose NATB scores predicted "sticcess and who actually did succeed both during and following their JOP training. For example, these treinees were hired following their JOP experience and were still employed gix months leter. The second group comprised those trainees who experienced failure elther during or imediately following their JOP experi- ence even though thetr NATB scores predicted they would be successfur. In other words, these individuals were either fired during their JoP training or imediately following the training period. From the total number of trainees in-these two groups, a random sampling was drawn of 59 individuals.

Group A consisted of those trainees who were successful during and imediately following their JOP experience. There was a total of 36 trainees in this group. The group contained 18 males and 18 females, evẹn though selected at random. 
Group B was composed of those trainees who experienced failure either during or imediately following JOP training. There was a total of 23 trainees in this group. The group consisted of 17 males and 12 females, again picked randomly.

A questionnaire based on the Coping Scale (Neff, 5) was developed and submitted to at least two staff members who had been woll acquainted with each individual trainee: The Coping Scale is designed to evaluate seven different styles of coping behavior (see Appendix C). These coping styles are:

1. Dependent

2." Fearfur

3. ImpaIsive

4. Socially Naivo

5. Withdrawn, Apathotic

6. Self-deprecatory

7. Hostile

On the questionnaire, each coping stylo is followed by a brlef

description. The raters were asked to rate each individual in terms of

the predominance of a given trait. The behaviors are listed on a four point scalo. 1. . Very Predominant

2. Somowhat Predominant

3. "Slightly Predominant

4. Not Predominant

The questionnaires were delivered to departmental supervisors at Fairviow Hospital and Training Center who, in turn, distributed tho questionnaires to appropriate personnel. Al1 questionnaires were returmed for each individual trainee included in this study. 
It was expected that there would be significant differences in the total scores, obtained by using the Coping Scale, between Group A and Group B. Although it was not expected that each of the seven areas of coping behavior examined would vary per group, it was felt that one or two areas would show substantial differences. It was also felt that the rating performed by the Social Worker would closely correspond with that rating done by the cottage worker.

It is interesting to note that neither of these predictions came true. There was no significant difference in the scores obtained by Group A and Group-B as-rated by cottage staff and SocIal Workers; and that the ratings completed by the Social Workers did not necessarily correspond closely with the ratings done by the cottage staff.

Using the total scores obtained on the Coping Scale done by both the Social Worker and the cottage staff a $T$ test was done to determine if there was any difference between males and females on coping scores in those individuals who achieved sucçess during and following their JOP training (Group A). The T test revealed that in Group A there were no differences in coping behaviors between males and females. See Table I on page 77.

Again, using the total scores obtained on the Coping Saale as rated by the. Social Worker and cottage staff, a T test, computed as $t=\frac{\left|\bar{x}_{1}-\bar{x}_{2}\right|}{\bar{x} \bar{x}_{1}-\bar{x}_{2}}$ was performed in an effort to determine where, if any, sex. differences appeared in Group B, those trainees who, although their NATB scores predicted success, were not successful. It is noted that 


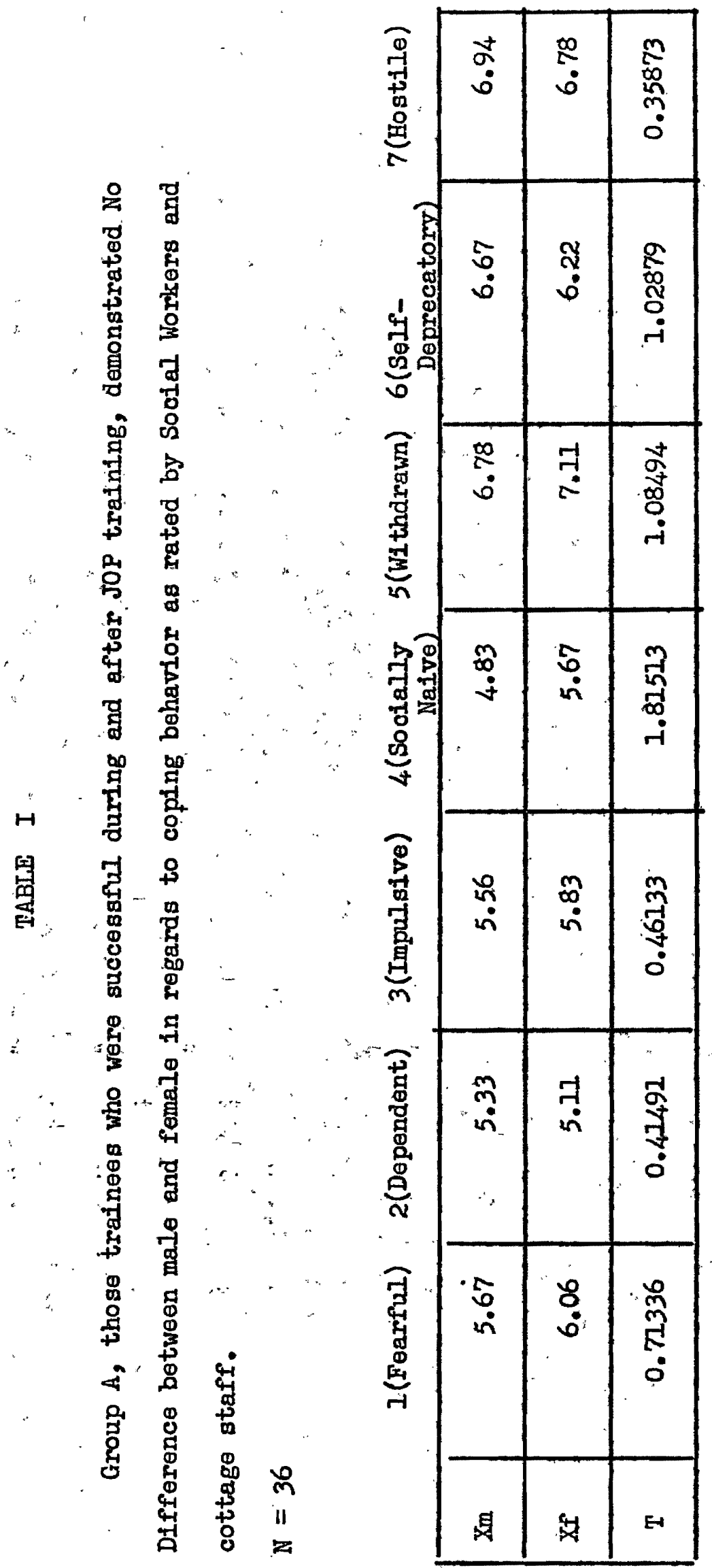


there were no significant differences between males and females in coping behavior. See Table II on page 19.

A composite of Group A and Group B is shown in Table III, which indicates that there were no significant differences between males and females in Group A and males and females in Group B. See Table III on page 20.

Using the $T$ test a comparison of the mean scoreg obtained on the Coping Scale for Group A was made. The mean scores as rated by the Social Worker were compared to the mean scores as rated by the cottage staff. This revealed that there was aignificant difference betwren the Social. Worker and cottage rating in the hostile category. See Table IV on page 21.

A comparison of the means of Group $B$ as rated by the cottage staff and the Social Worker revealed no significant difference between the two ratings, See Table $V$ on page 22 . 


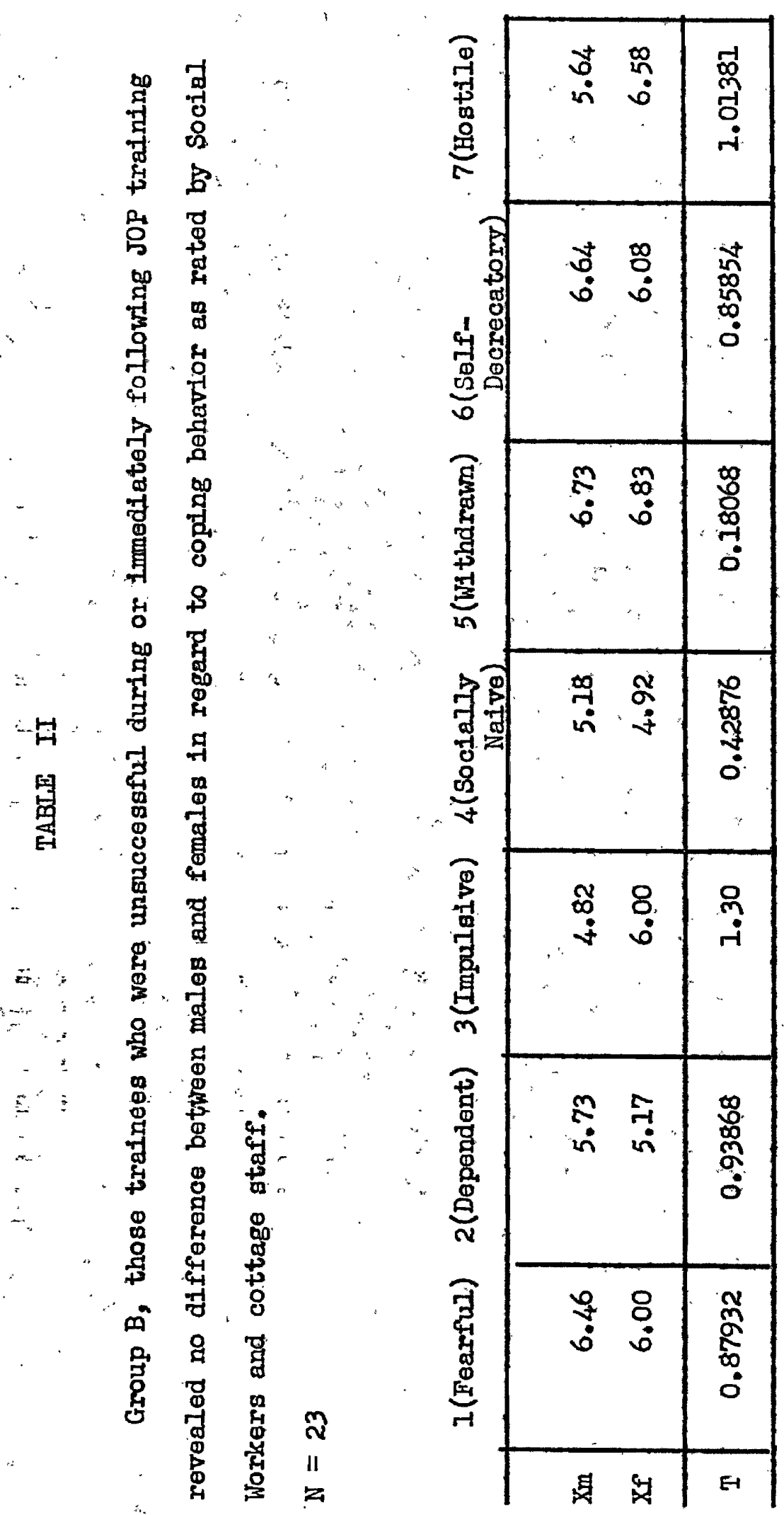




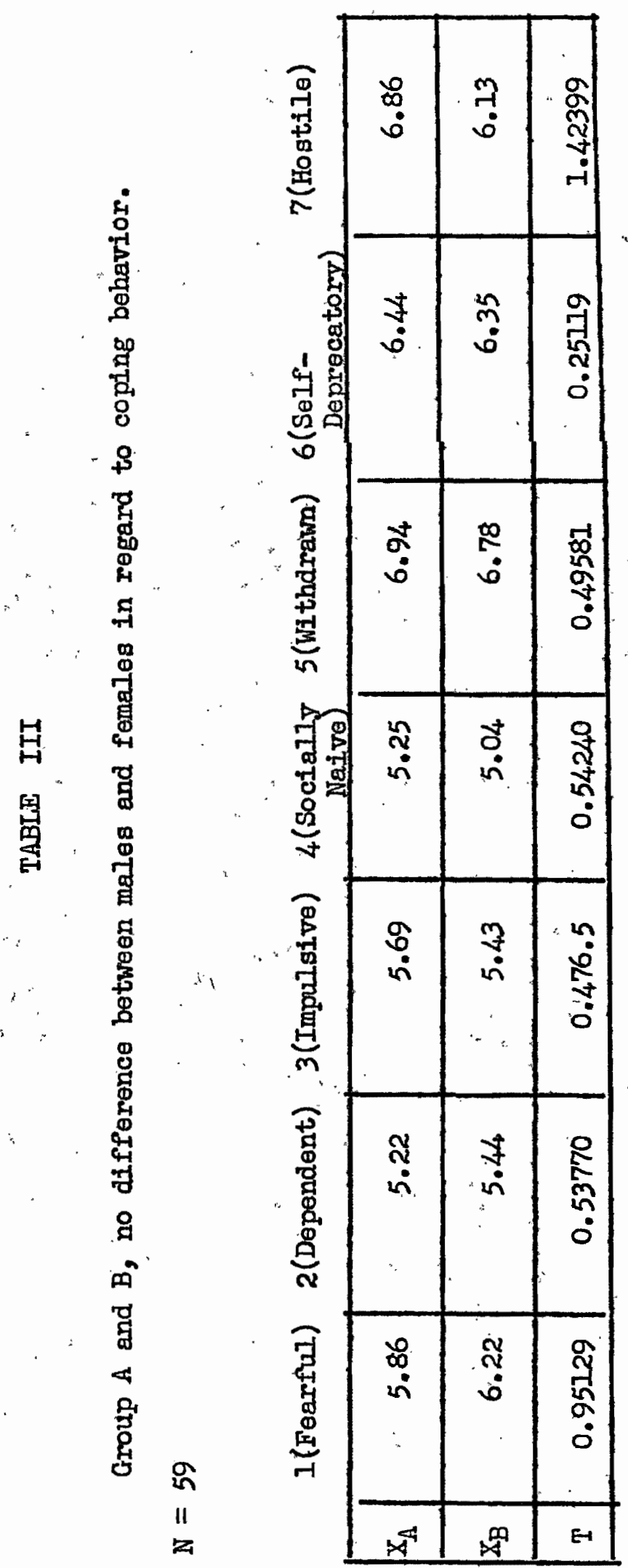




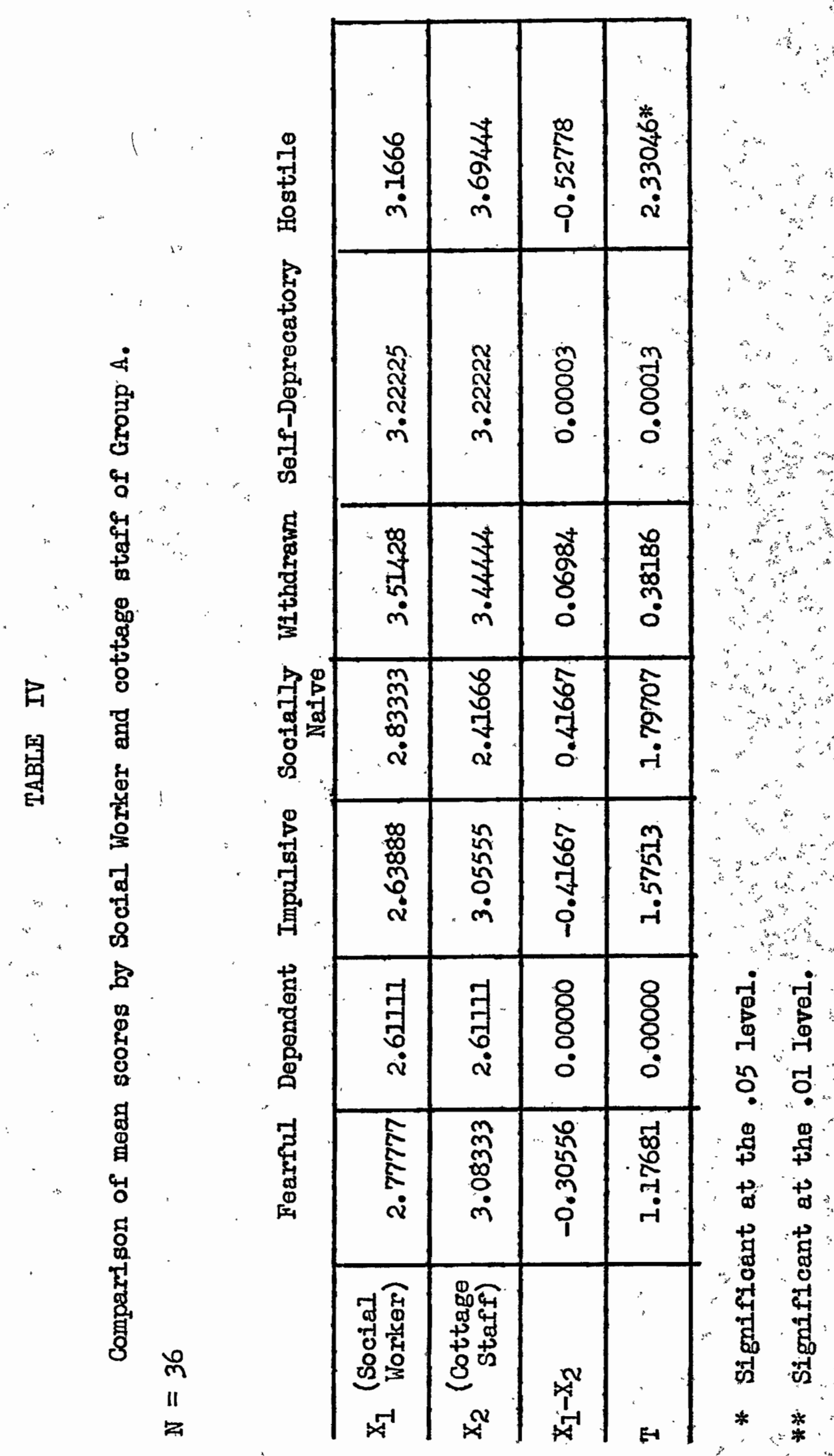




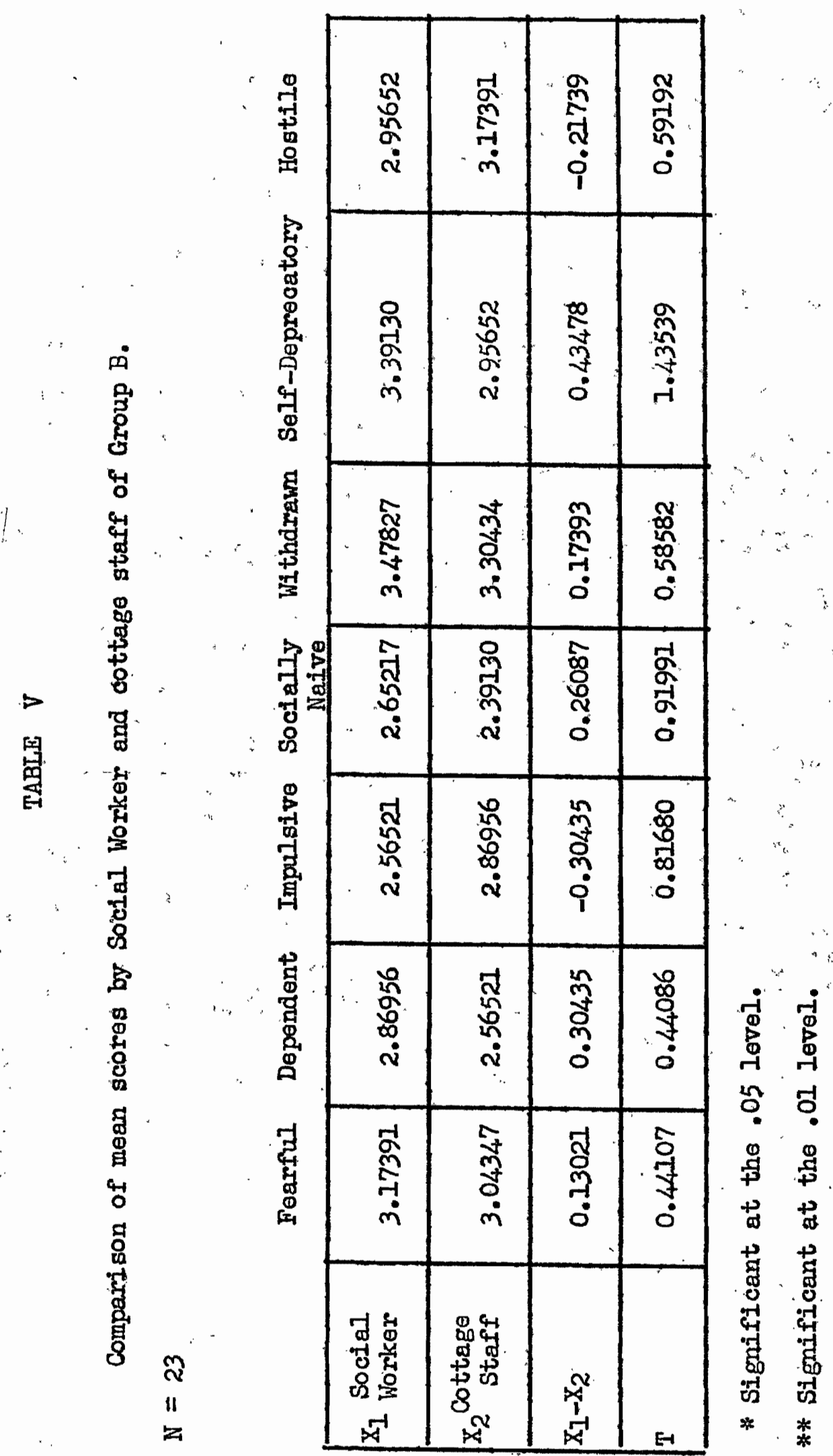


A comparison was then made between the mean scores of Group A and Group B using only the ratings done by the cottage staff. As rated by the cottage staff there was no significant difference in Group A whan compared to Group B. See Table VI on page 24.

Using the $T$ test again, a comparison was made betwien Group $A$ and Group $B$ as rated only by the Social Worker. The mean scores revealed that in the seven areas of coping style, thers was no significant difference between the two groups. Table VII is found on page 25.

The means, standard deviations, ranges, and Pearson Product movement correlations of the ratings by the cottage staff and the Sacial Worker were then combined for Group A and Group B. There were two significant differences noted; one in the impulsive category and one in the hostile category. However, these two significant correlations mean. only that there was a signiflcant discrepancy in the rating given by the Social Worker and the cottage staff with respect to the amount of hostility and impulsivity of the subjects. See Table VIII on page 26.

The standard deviation is computed as follows:

$$
S_{1}=\frac{\sqrt{\Sigma x_{1}^{2}}-\left(\Sigma_{X_{1}}\right)_{2}^{2}}{N_{1}} \quad \quad S=\frac{\sqrt{N Z \times Z-(\Sigma \times)^{2}}}{N_{2}}
$$

The basio computational formula for the Pearson product-movement correlation is:

$$
\sum \quad r=\frac{N \Sigma x y-(\Sigma x)(2 y)}{\left.\sqrt{\left[N \Sigma x^{2}-(\varepsilon x)^{2}\right]\left[N \leqslant y^{2}\right.}-(\Sigma y)^{2}\right]}
$$




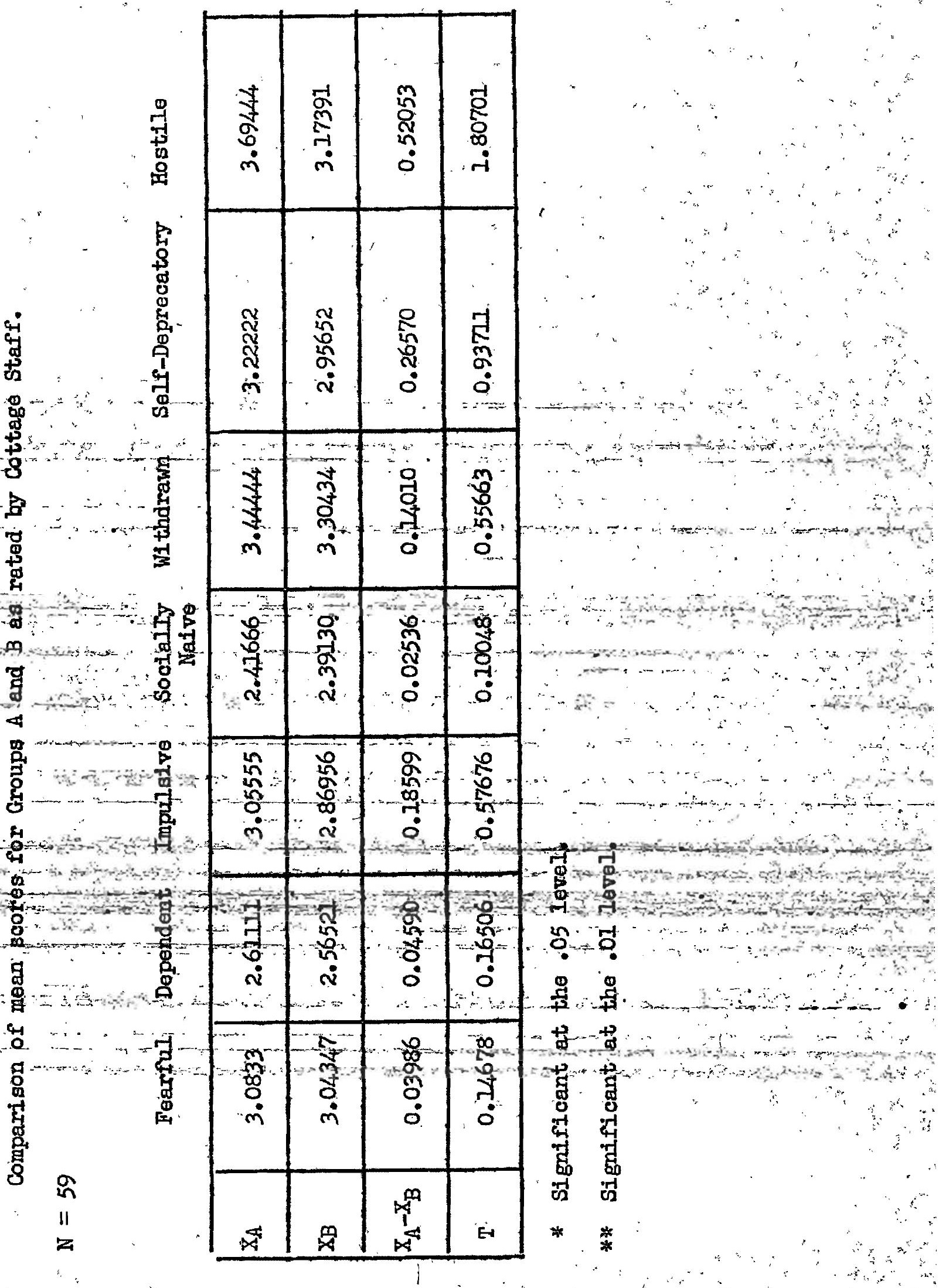




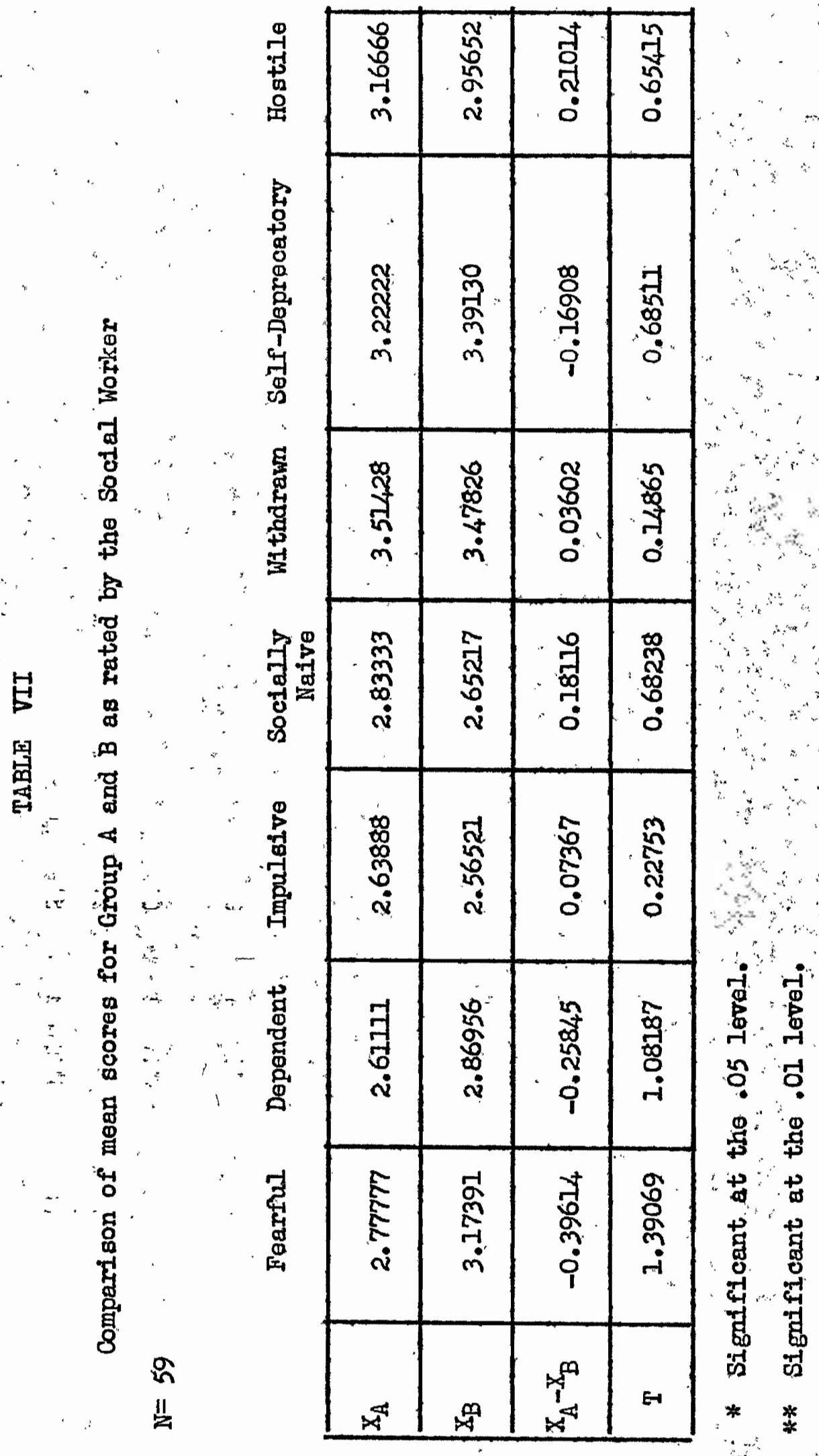




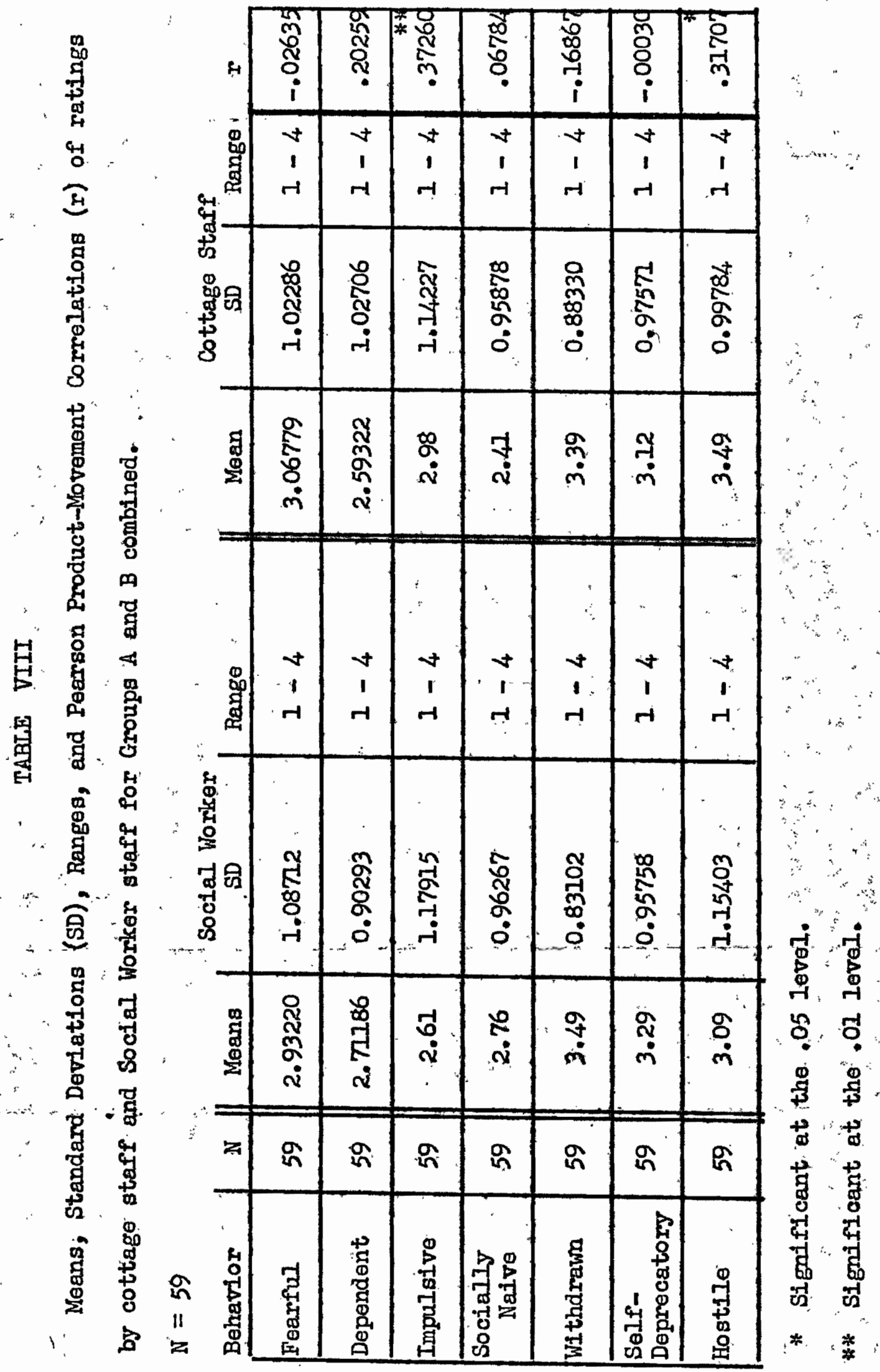




\section{EVALUATTON}

The data contained in this study does not indicate that there was any noticeable difference in coping style between those trainees in Group A and those trainees in Group B. In two categories on the Coping Scale (impulsivity and hostility) there was a difference in the way in which the Social Worker and the cottage staff rated the trainees. It is possible that this difference betwen the two ratings was significant enough to affect the rest of the scores on the Coping Scale. Further research and data processing would be necessary in order to prove. or disprove this.

The difference botwen the Social Worker and cottage staff ratings on hostility and impulaivity may indicate that there is somo lack of communication between these professionals.

It is probably true that the cottage staff, with their increased exposiure to the residents, would view the resident differently than Would the Social Worker who, at most, would have contact with a resident for only a few hours a weok and usually under different circumstances than does the cottage staff.

However, communications should be such that the Social Worker should be aware of how each resident responds to cottage staff and the reverse should also be true.

While this study did not reveal any significant difference between Group $A$ and Group $B$, it is felt that differences do exist. In further evaluating this study and the study performed by Neff and Koltur (6) there appears to be one gross difference. In the study undertaken by 
Neff and Koltuv (6) they eveluated psychiatric residents participating in a rehabilitation program upon first entering the program and again after each resident was either dropped from the program or successfully completed the rocational training. Thus, each resident was ovaluated at a time when the individual was well known to the rater.

The study performed at Fairview Hospital and Training Center consisted of a random selection of those individuals whose NATH scores predicted success and who were either successful or unsuccessful during the JOP training." Some of the individuals picked for the study had participated in the MDT-JOP program five years previously and the raters were required to score these individuals from memory which could account for some error in rating.

Secondly, it was later discovered that three of the individuals in Group B who did not successfully complate their JOP training were successful in jobs they located for themselves following their failure. In other words, the loss of their first job may have been the fault of the employer rather than the trainee. These three individuals could have greatly affected the total scores of Group B and further research would be necessary in order to prove or disprove their influence upon the total ratings.

Because of these two errors in design, 1) the test requiring a flive year memory spen and 2) the later discovery of individuals who probably should not have been included in Group B, the Coping Scalo is a tool that should be definitely administered again to the MDT-JOP trainees. However, it should be done under more controlled situations and each beginning trainee should be rated at the start of the NDI 
program and again at completion of the program or upon being dropped from the program.

This study has been unsuccessful in demonstrating the value of the Coping Sceale, but neither has it demonstratẹd that the Coping Scale is of no value. Further research is definitely indicated and will hopefully be undertaken by the Vocational Training Department at Fairview Hospital and Training Center. 
Factor Structure of the Nonreading Aptitude Test Battery (NATB) and the Separate Tests Comprising the Test Battery. Factor I (space) "Non-verbal Intelligence"

Measured by tes̀ts 6. Three-Dimensional Space

7. Form Matching

Factor II (perceptual speed)

Measured by tests 5. Tool Matching

6. Letter Cancellation *

Factor III (Internalization)

Measured by teats 4. Matrices

7. Coin Series

Factor IV (General Learning Ability)

Measured by tests 1. Picture-Word Matching

2. Oral Vocabulary

Factor V (Dexterity)

Measured by tests 11. Mark Making

12. Place

13. Tum

14. Assembio

15. Disassemble *

a. Source: Droege, R.C. and Hawk, J. A Factional Investigation of Nonreading Aptitude Tests. U. S. Department of Labor Manpowsr Administration, Washington, D.C. U. S. Training and Enployment Service, 1970.

* Tests used in present study. 
Rating Form completed by OJT supervisor with $i=$ poor, $2=$ fair, $3=$ everage, $4=$ good, and $5=$ excellent.

I. How consistent is his or her job performance?

2. How quickly and well does he ox she learn to perform the different tasks?

3. How much ability does he or she have for using the equipment necessary to perform the job tasks?

4. How much ability does he or she have for maintaining adequate production?

5. How good was the quality of his or her work during the training?

6. How large a variety of job tasks could he or she perform adequately?

7. How resourceful is he or she in coping with new situations that are out of the ordinery?

8. Considering all the factors rated, and only these factors, how acceptable was his or her performance during the training?

9. Total points from the preceeding eight questions. 
Directions: Please read the "suggestions to raters" and then fill in the items which follow. In making your ratings, only one box should be checked for each question.

\section{SUGGESTIONS TO RATERS}

We are asking you to rate the bohavior of individuals you have known or who have worked for you. These ratings will serve as a "Yardstick" agatnst which we can compare the test scores in this study. The ratings must give a true picture of each individual or this study will have very little value. You should try to give the mast accurate ratings possible for each individual.

These ratings are strictly confidentlal and won't affect these individuals in any way. Neither the ratings nor test scores of any individual will be shown to any one not directly involved with the study. We are interested only in "testing the tests".

In making ratings, don't let general impressions or some outstanding trait affect your judgment. Try to forget your personal feelings about the individual. Here are some more points which might help jou.

1. Please read all directions and the ratings scale thoroughly before rating.

2. For each question compare this individual with "people in general".

3. A suggested method is to rate each individual on one question at a time. The questions ask about different behaviors of the individual.

4. Rate the individuals according to their behavior over a period of several weeks or months. Do not rate on the basis of one "good day" or one "bad day". Think in terms of the individual's usual or typical behavior.

Neme of Person Being Rated

Rated by:

How long have you known this person?

( ) $\left\{\begin{array}{l}\text { less than } 1 \text { month } \\ 1-2 \text { months } \\ 3-5 \text { months } \\ 6 \text { months or longer }\end{array}\right.$ 
1. This person was fearful. He exhibited these or similar behaviors: may be tense; fidgety; jumpy; uneasy; may be frequently troubled or. worried; may be afreta and timid in relationships with others; may be afraid to establish contact with others; may seem mousy, may shy away from things and people.
( ) Very predominant
( ) Somewhat predominant
( ) Slightly predominant
( ) Not predominant

2. This person was dependent. He exhibited these or similar behaviors: may frequently ask help from others; meiy rely on others for support; may be unable to initiate action on his own; may place himself in the position of making others direct him; may be highly compliant; may seek others' approval.
( ) $\begin{aligned} & \text { Very predominant } \\ & \text { Somewhat predominant } \\ & \text { Slightly predominant } \\ & \text { Not predominant }\end{aligned}$

3. This person was impulsive. He exhibited these or similar behaviors: may rarely see a task through; may be unable to stick to a plan of action; may flit from one thing to another; may be unable to delay the gratification of his impulses; may immediately seek to satisfy his desires; may easily become enthusiastic about something and then rapidly Iose his enthusiesm.
( ) Very predominant
( ) Somewhat predominant
( ) Slightly predominant
() Not predominant

4. This person was socially naive. 'He exhibited these or similar behaviors: may be unperceptive when it comes to the needs or feelings of others; may not realize that his behavior elicits reactions from others or has an effect on them; may be socially inept; may not seem to know what is appropriate in ordinary sacial situations.
( ) Very predominant
() Somewhat predominant
( ) Slightly predominant
( ) Not predominant

5. This person was withdrawn, apathetic. He exhibited these or similar behaviors: may be blandf 20 thargic; may lack thtality; may Give the impression of being indifferent to things going on around him; may lack emotional responsivity; may seem very easygoing and uninvolved.

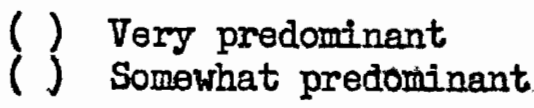



( ) SIightly predominant

6. This person was self-deprecatory. He exhibited these or similar behaviors:- may point up and willingly talk about his deficiencies; may be highly self-critical; may talk about his ineptitude; may derogate his qualities and abilities; may generally run himself down; may express self-doubts.

( ) $\begin{aligned} & \text { Very predominant } \\ & \text { Somewhat predominant } \\ & \text { Slightly predominant } \\ & \text { Not predominant }\end{aligned}$

7. This person was hostile. He exhibited these or similar behaviors: may be angry with others most of the time; may bo subtly negativistic; may contradict and argue vith others; may do things to irritate and annoy others; may be sarcastic; may belittle or insult others; may criticize others.

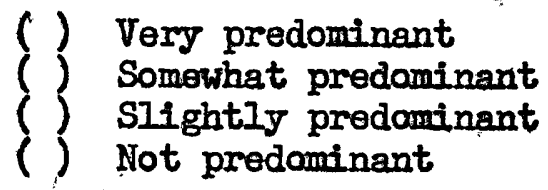


1. Carbuhr, Wayne M., Ph.D. and Ivan Wells, "Examining Some Parameters of the Work Personality of the Employed, Unemployed and Unemployable Mentally Retarded". Developmental Disability Research Series No. (presented at American Association on Mental Deficiency Region I Conference, October 14, 1972).

2. Carbouhn, Wayne M., Ph.D. and Ivan Wells, "Utilization of Non Reading Aptituda Tests (NATB) for Selecting Institutionalized Mentally Retarded Residents for Competitive Employment". Developmental Disabłlities Research Series, No.

3. Carbuhn, Wayne M., Ph.D. and Ivan WeIls, "Utilization of the NATB as an Alternative to the VAIS and WRAT for Selecting InstitutionsIized Mentally Retarded Residents for Competitivo Froloyment". Developmental Disabilities Research Series, No. 6, July, 197.

4.. Droege, R. C. and J. Hawk, "A Factorial Investigation of Nonreading Aptitude Tests!". U. S. Department of Labor Manpower Administration, Washington, D. C. U. S. Training and Employment Service, 1970.

5. Neff, Walter S., Work and Human Behavior. New York Atherton Press," í68.

6. Neff, Walter S: and Mron Koltiv, "Toleration for Psychiatric Rehabilitation as a Function of Coping Style". Joumal of Consulting Psychologr. Vol. 31, No. 4, 1967. (pp 364-370)

7. Secretary's Committee on Mental Retardation, "A Profile of M.R. Clients Rehabilitated During the Fiscal Year 1967". Program for the Handicapped. Vo1. 71-8, September 20, 1971. 
Abrams, Harvey A., "The Role of Social Work in Relocation for Employment". Social Casework, Vol. XIIX; No. 8, October, 1968.

Dalton, Juanita and Helene Epstein, "Counseling Parents of Mildiy Retarded Children". Social Casework, Vol. XIIV, No. 9, November, 1963.

El7ren, Lorme, "Predicting Productivity of Trainable Rotardates on Experimental Workshop Tasks". American Journal of Mental Deficiencr, $71(4)$, 1967. pp. 516-580.

Ellis, Norman R. (ed.), International Review of Research in Mental Retardation. New Iork Academic Press, 1966-1970. 4 vols.

Mandelbaum, Arthur and Mary EIIa Wheeler, M.B., "The Meaning of a Defective Child to Parenta". Social Casework, Vol. XII, No. 7, JuZ7; 1960.

Mental Retardation Abstracts. Washington, D. C., U. S. Department of Health Education and Welfare, 1964-1972. 9 Vols.

Moore, Jean E., "Relocation of People: A Challenging Aspect of Urban PloNewal and Redevelopment". Sociel Casework, Vol. XIVII, No. 10, December, 1966.

0lsharsley, Simon, "Chronic Sorrow: A Response to Having A Mentelly Defec-" tive Child". Social Casework, VoI. XIIII, No. 4, April, 1962.

Panter, Ethel J., "Ego-building Procedures That Foster Social Functioning". Social Casework. Vol. XLVII, No. 3, March, 1966.'

Sanders, Josephine P., "A Pilot Course in Iifemanship for Severely Retarded Youth". Exceptional Ghildren. 35 (9), 1969. pp. 747-748. 